University of Nebraska - Lincoln

DigitalCommons@University of Nebraska - Lincoln

Publications from USDA-ARS / UNL Faculty

U.S. Department of Agriculture: Agricultural

Research Service, Lincoln, Nebraska

2011

\title{
Carbon exchange by establishing biofuel crops in Central Illinois
}

\author{
Marcelo Zeri \\ Instituto Nacional de Pesquisas Espaciais, marcelo.zeri@inpe.br \\ Kristina Anderson-Teixeira \\ University of Illinois at Urbana-Champaign, teixeirak@si.edu \\ George Hickman \\ University of Illinois at Urbana-Champaign \\ Michael Masters \\ University of Illinois at Urbana-Champaign \\ Evan DeLucia \\ University of Illinois at Urbana-Champaign \\ See next page for additional authors
}

Follow this and additional works at: https://digitalcommons.unl.edu/usdaarsfacpub

Part of the Agricultural Science Commons

Zeri, Marcelo; Anderson-Teixeira, Kristina; Hickman, George; Masters, Michael; DeLucia, Evan; and Bernacchi, Carl J., "Carbon exchange by establishing biofuel crops in Central Illinois" (2011). Publications from USDA-ARS / UNL Faculty. 832.

https://digitalcommons.unl.edu/usdaarsfacpub/832

This Article is brought to you for free and open access by the U.S. Department of Agriculture: Agricultural Research Service, Lincoln, Nebraska at DigitalCommons@University of Nebraska - Lincoln. It has been accepted for inclusion in Publications from USDA-ARS / UNL Faculty by an authorized administrator of DigitalCommons@University of Nebraska - Lincoln. 


\section{Authors}

Marcelo Zeri, Kristina Anderson-Teixeira, George Hickman, Michael Masters, Evan DeLucia, and Carl J.

Bernacchi 


\title{
Carbon exchange by establishing biofuel crops in Central Illinois
}

\author{
Marcelo Zeri ${ }^{\mathrm{a}, \mathrm{b}, *}$, Kristina Anderson-Teixeira ${ }^{\mathrm{b}}$, George Hickman $^{\mathrm{b}}$, Michael Masters ${ }^{\mathrm{b}}$, \\ Evan DeLucia $^{\mathrm{b}, \mathrm{c}, \mathrm{d}}$, Carl J. Bernacchi ${ }^{\mathrm{b}, \mathrm{c}, \mathrm{e}}$ \\ a Centro de Ciência do Sistema Terrestre, Instituto Nacional de Pesquisas Espaciais, Cachoeira Paulista, SP, Brazil \\ b Energy Biosciences Institute, University of Illinois at Urbana-Champaign, Urbana, IL, USA \\ ${ }^{c}$ Department of Plant Biology, University of Illinois at Urbana-Champaign, Urbana, IL, USA \\ ${ }^{\mathrm{d}}$ Institute of Genomic Biology, University of Illinois at Urbana-Champaign, Urbana, IL, USA \\ e Global Change and Photosynthesis Research Unit, Agricultural Research Service, USDA, Urbana, IL, USA
}

\section{A R T I C L E I N F O}

\section{Article history:}

Received 5 November 2010

Received in revised form

15 September 2011

Accepted 16 September 2011

Available online 14 October 2011

\section{Keywords:}

Biofuels

Maize

Miscanthus

Switchgrass

Prairie

Carbon balance

Eddy covariance

\begin{abstract}
A B S T R A C T
Perennial grass biofuels may contribute to long-term carbon sequestration in soils, thereby providing a broad range of environmental benefits. To quantify those benefits, the carbon balance was investigated over three perennial grass biofuel crops - miscanthus (Miscanthus $\times$ giganteus), switchgrass (Panicum virgatum) and a mixture of native prairie plants - and a row crop control (maize-maize-soy) in Central Illinois, USA, during the establishment phase of the perennial grasses (2008-2011). The eddy covariance technique was used to calculate fluxes of carbon dioxide and energy balance components, such as latent and sensible heat fluxes. Whereas maize attained the highest maximal carbon uptake rates, the perennial grasses had significantly extended growing seasons, such that their total carbon uptake rivaled that of corn in the second growing season and greatly exceeded that of soy in the third growing season. To account for the removal of carbon through harvest, net ecosystem exchange of carbon (NEE) was combined with estimates of yields, resulting in the net ecosystem carbon balance (NECB). After 2.5 years, NECB for the maize/soybean plot was positive (a source of carbon), while the grasses were a sink of carbon. Continuous measurements over the next years are required in order to confirm whether miscanthus, switchgrass and prairie can sustain a long-term sink of carbon if managed for biofuels, i.e., if harvested annually.
\end{abstract}

(C) 2011 Elsevier B.V. All rights reserved.

\section{Introduction}

Clean and renewable sources of energy such as wind, solar and bioenergy comprise a valuable set of options available to deal with the pressing issues of energy security and climate change mitigation. Conversion of lignocellulosic plant material to liquid fuel (i.e., second-generation biofuels) holds promise as a more energetically efficient and environmentally beneficial alternative to the production of maize ethanol. In recent years, methods of bioconversion have been extensively investigated and improved in order to increase the efficiency of converting plant material to liquid fuels. Microbial engineering and different chemical pathways are methods that are currently being investigated by several groups, as reviewed in Fortman et al. (2008). Lignocellulosic biofuels have the potential for higher energy yields than maize ethanol, and would therefore require less land to cultivate the same quantity of fuel (e.g., Heaton et al., 2008; Robertson et al., 2008; Somerville

\footnotetext{
* Corresponding author at: Centro de Ciência do Sistema Terrestre, Instituto Nacional de Pesquisas Espaciais, Rod. Presidente Dutra, km 40, 12630-000, Cachoeira Paulista, São Paulo, Brazil.

E-mail address: marcelo.zeri@inpe.br(M. Zeri).
}

et al., 2010). In addition, some species used in second-generation biofuels have environmental benefits, such as carbon sequestration (Anderson-Teixeira et al., 2009), reduced nitrate leaching (Hill et al., 2009; Tilman et al., 2009; McIsaac et al., 2010), improved air quality (Hill et al., 2009), increased biodiversity (Jordan et al., 2007), increased soil fertility (Lal, 2004), and improved retention and availability of water and nutrients (McLaughlin and Walsh, 1998). The bioenergy growth thus holds potential to positively contribute to environmental issues on both the farm and global scale (Robertson et al., 2008). An urgent question is how the cycles of water, carbon and nitrogen on local to continental scales will be influenced if lignocellulosic crops are to be extensively cultivated for production of second-generation biofuels.

The choice of species suitable for biofuel production should focus on several factors such as high yields, greenhouse gas mitigation, recycling of nutrients, and water use efficiency (Heaton et al., 2004, 2008; Hill et al., 2009; Somerville et al., 2010). Miscanthus (Miscanthus $\times$ giganteus), a high-yielding perennial grass widely studied as a energy crop in Europe (Lewandowski et al., 2000; Heaton et al., 2008); switchgrass (Panicum virgatum L.), a productive perennial grass native to North America selected by the U.S. Department of Energy as a model energy crop (McLaughlin and Adams Kszos, 2005; Liebig et al., 2008), and low-input 
high-diversity mixtures of native species (Tilman et al., 2006) meet several of those requirements and are good candidates for cellulosic biofuel crops. All three have the potential to out-perform maize ethanol in terms of energy yield, greenhouse gas mitigation (Tilman et al., 2006; Adler et al., 2007; Heaton et al., 2008; Hill et al., 2009; US_EPA, 2010), and environmental services rendered (McLaughlin and Walsh, 1998; Tilman et al., 2006). Moreover, the perennial nature of these crops-as well as nitrogen fixation in some-imply reduced need for nitrogen fertilizer and reduced nitrate leaching (Tilman et al., 2006; Davis et al., 2010; Mclsaac et al., 2010). A recent review of data published on changes in soil organic carbon (SOC) following conversion of natural or agricultural lands to biofuel crops found that cultivation of perennial grasses such as miscanthus, switchgrass, or native mixes resulted in a net accumulation of SOC, which represents a climate benefit beyond the displacement of fossil fuels (Anderson-Teixeira et al., 2009).

Perennial rhizomatous grass crops sustain high yields without replanting for a decade or more. Yields increase during the establishing years before reaching the equilibrium phase, when harvestable aboveground biomass reaches a constant level. The full establishment might take 3-5 years, for miscanthus and switchgrass (Lewandowski et al., 2000; Heaton et al., 2004), while the successful establishment of native prairie stands might take 2-5 years (NRCS, 2011).

In this study, the carbon cycle of three potential perennial grass biofuel crops in their establishment phase-as well as a control of row crop agriculture typical of the region (maize-maize-soy rotation)-is analyzed by integrating measurements of continuous fluxes of $\mathrm{CO}_{2}$ between plants and the atmosphere with biomass inventories. This study is the first side-by-side comparison of the carbon balance of bioenergy crops in plots that are large enough to enable the use of high frequency continuous monitoring (eddy covariance technique). These measurements were made as part of a larger research project whose objective is to quantify the major pools and fluxes in the biogeochemical cycles of carbon, nitrogen and water in these biofuel crops and to determine how and on what timescale interactions with soil microbial and insect populations affect these biogeochemical cycles. The objective of this paper is to describe net ecosystem exchange of $\mathrm{CO}_{2}$ during the establishment phase of agro-ecosystems planted for bioenergy purposes, represented here by the first three growing seasons following the establishment in Spring 2008. We also compare the evolution of the carbon cycle for each species throughout the year as they were influenced by the local climate and management practices.

\section{Materials and methods}

\subsection{Site and data}

The site is located in Urbana, IL, USA, at a University of Illinois research farm ("Energy Farm"; $40^{\circ} 3^{\prime} 46.209^{\prime \prime} \mathrm{N}, 88^{\circ} 11^{\prime}$ $46.0212^{\prime \prime} \mathrm{W}, \sim 220 \mathrm{~m}$ above sea level). According to the Illinois State Water Survey historic climate data, averaged from 1979 to 2009 , the mean annual temperature was $11.1^{\circ} \mathrm{C}$ while the mean accumulated rainfall was $1041.7 \mathrm{~mm}$ per year. For the three years used in this study (2008, 2009 and 2010), the average temperature was $10.3^{\circ} \mathrm{C}, 10.7^{\circ} \mathrm{C}$ and $11.5^{\circ} \mathrm{C}$, respectively. The climate is highly seasonal, with monthly average air temperatures below $0{ }^{\circ} \mathrm{C}$ from December to February and above $20^{\circ} \mathrm{C}$ from June to August (Fig. 1A). Accumulated rainfall in 2008, 2009 and 2010 was $1335.5 \mathrm{~mm}, 1301.8 \mathrm{~mm}$ and $931.4 \mathrm{~mm}$, respectively. Wind direction frequency of occurrence is evenly distributed between the south, northeast and west-northwest sectors (result not shown).

The experimental plots were 4 ha in size each $(200 \times 200 \mathrm{~m})$, arranged in a $2 \times 2$ grid. Prior to this experiment, the fields were planted with oats. In spring 2008, the plots were planted with maize (6 May 2008), miscanthus (2-16 June 2008), switchgrass (28 May 2008) and a mix of 28 native prairie species (29 May 2008). The species composition in the prairie plot can be seen in Table 1. Crops were planted and managed according to standard agricultural practices for the region (maize) or best-known management practices (perennial grasses). Specifically, prior to planting, diammonium phosphates, potash and lime were added by VRT (variable-rate technology) to achieve uniform soil fertility
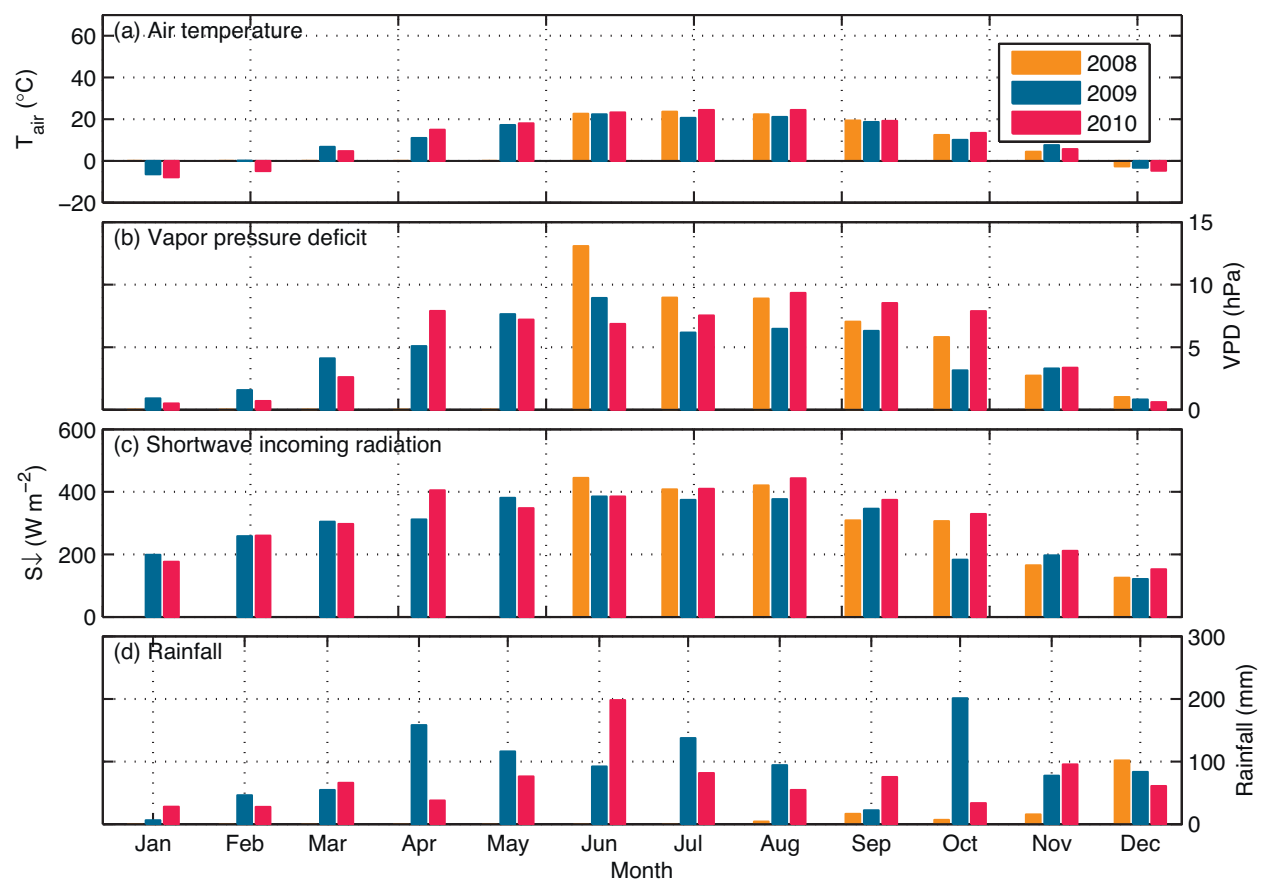

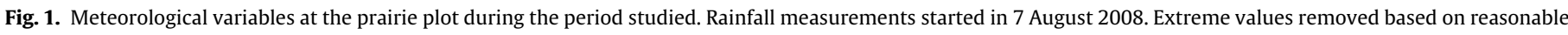
limits for each variable. Spikes removed using a moving window algorithm. 
Table 1

Species composition and relative abundance of the restored prairie plot.

\begin{tabular}{|c|c|c|c|c|c|}
\hline Scientific name & Common name & $\mathrm{Ab}$ & Family & Growth form & Group \\
\hline Andropogon gerardii & Big bluestem & 5 & Poaceae & Graminoid & Monocot \\
\hline Aster novae-angliae & New England Aster & 3 & Asteraceae & Forb/herb & Dicot \\
\hline Astragalus canadensis & Canada Milk Vetch & 2 & Fabaceae & Forb/herb & Dicot \\
\hline Baptisia leucantha & White Wild Indigo & 2 & Fabaceae & Forb/herb & Dicot \\
\hline Carex bicknellii & Bicknell's sedge & 3 & Cyperaceae & Graminoid & Monocot \\
\hline Coreopsis palmata & Stiff tickseed & 1 & Asteraceae & Forb/herb & Dicot \\
\hline Coreopsis tripteris & Tall tickseed & 5 & Asteraceae & Forb/herb & Dicot \\
\hline Desmodium canadense & Showy tick trefoil & 4 & Fabaceae & Forb/herb & Dicot \\
\hline Echinacea pallida & Pale purple coneflower & 2 & Asteraceae & Forb/herb & Dicot \\
\hline Elymus canadensis & Canada wild rye & 5 & Poaceae & Graminoid & Monocot \\
\hline Helianthus grosseserratus & Sawtooth sunflower & 5 & Asteraceae & Forb/herb & Dicot \\
\hline Heliopsis helianthoides & Early sunflower & 5 & Asteraceae & Forb/herb & Dicot \\
\hline Lespedeza capitata & Round Head Bush. & 3 & Fabaceae & Forb/herb & Dicot \\
\hline Monarda fistulosa & Wild bergamot & 4 & Lamiaceae & Forb/herb & Dicot \\
\hline Parthenium integrifolium & Wild quinine & 2 & Asteraceae & Forb/herb & Dicot \\
\hline Penstemon digitalis & Foxglove beardtongue & 1 & Scrophulariaceae & Forb/herb & Dicot \\
\hline Dalea purpurea & Purple prairie clover & 2 & Fabaceae & Forb/herb & Dicot \\
\hline Pycnanthemum virginianum & Common mountain mint & 3 & Lamiaceae & Forb/herb & Dicot \\
\hline Ratibida pinnata & Yellow coneflower & 5 & Asteraceae & Forb/herb & Dicot \\
\hline Rudbeckia subtomentosa & Sweet blackeyed Susan & 5 & Asteraceae & Forb/herb & Dicot \\
\hline Schizachyrium scoparium & Little bluestem & 5 & Poaceae & Graminoid & Monocot \\
\hline Silphium integrifolium & Rosin weed & 4 & Asteraceae & Forb/herb & Dicot \\
\hline Silphium laciniatum & Compass plant & 2 & Asteraceae & Forb/herb & Dicot \\
\hline Silphium perfoliatum & Cup plant & 3 & Asteraceae & Forb/herb & Dicot \\
\hline Silphium terebinthinaceum & Prairie dock & 2 & Asteraceae & Forb/herb & Dicot \\
\hline Solidago rigida & Stiff goldenrod & 5 & Asteraceae & Forb/herb & Dicot \\
\hline Sorghastrum nutans & Indian grass & 1 & Poaceae & Graminoid & Monocot \\
\hline Veronicastrum virginicum & Culver's root & 1 & Scrophulariaceae & Forb/herb & Dicot \\
\hline
\end{tabular}

Abundance (Ab): (5) Very common, (4) common, (3) rare, (2) Very rare, (1) null.

(pH 6.0, P: $50.4 \mathrm{~kg} / \mathrm{ha}, \mathrm{K}: 336 \mathrm{~kg} / \mathrm{ha}$ ). Maize and miscanthus were sown with $75 \mathrm{~cm}$ between rows, and switchgrass and prairie were broadcast seeded. For switchgrass and prairie, oats were seeded along with the target crops to serve as a cover crop during establishment of the perennials. Nitrogen fertilizer was applied to maize in the spring of 2008 (168 kg/ha; 6 May 2008) and 2009 (201.6 kg/ha; 12 May 2009). Perennial grasses were not fertilized during this time period. Miscanthus was irrigated with approximately $13 \mathrm{~mm}$ of water in 21 May 2009 and again in 22 May 2010 for establishment only. Herbicides were applied for weed control in the maize (Lumax applied 6 May 2008 and 12 May 2009; Roundup applied 2 July 2008), miscanthus (Prowl applied 16 June 2008, 2,4-D applied 16 July 2008, Accent applied 14 July 2009), and switchgrass (2,4-D applied 8 August 2008) plots. Switchgrass and prairie plots were mowed periodically during the first season (30 June, 17 July, and 4 September 2008) to give competitive advantage to the target species, and residues were left on the field. Maize was harvested on 28 October 2008, tilled on 29 October 2008, replanted on 12 May 2009 , rotary hoed to break up surface crust in order to facilitate emergence on 22 June 2009, harvested again on 3 November 2009, and plowed again on 12 November 2009. The same plot was cultivated on 24 May 2010 for soybean; prowl (endimethalin) herbicide was applied and incorporated on the same day. Soybeans were planted on 25 May 2010, Roundup (glyphosate) was spot applied as needed (mostly around sampling points) on 28 June 2010, and on 12 October 2010 this plot was harvested. The perennial grasses (switchgrass and prairie) were harvested on 15 March 2010. After that, switchgrass was fertilized with $56 \mathrm{~kg} / \mathrm{ha}$ of nitrogen (as granular urea) on 21 April 2010 and harvested on 19 November 2010; the restored prairie plot received no other management after the harvest on 15 March 2010. A die-off of miscanthus rhizomes occurred during a period of low temperatures in December 2008, causing the vegetation cover in that plot to be sparse in 2009. For that reason, miscanthus was replanted on 19-21 April 2010 and bicep (metolachlor + atrazine) herbicide was applied on 21 April 2010.

An eddy covariance system, along with several micrometeorological instruments, was situated in the center of each plot.
The eddy covariance system consisted of a 3D sonic anemometer (model 81000 V, R.M. Young Company, Traverse City, MI, USA) and an infrared gas analyzer (model LI-7500, LI-COR Biosciences, Lincoln, NE, USA), both operating at $10 \mathrm{~Hz}$. The auxiliary instrumentation consisted of a temperature and relative humidity probe (model HMP45C, Campbell Scientific, Logan, UT, USA); a barometer (model CS105, Campbell Scientific, Logan, UT, USA); radiation sensors for up- and down-welling shortwave and longwave components (model CNR1 4-channel net radiometer, Kipp \& Zonen, The Netherlands); quantum sensors for upwelling and downwelling photosynthetically active radiation (PAR; model LI-190, LI-COR Biosciences, Lincoln, Nebraska, USA); soil heat flux plates (model HFP01, Hukseflux Thermal Sensors B.V., The Netherlands); and soil moisture and soil temperature (model Hydra Probe II, Stevens Water Monitoring Systems, Inc., Portland, OR, USA). Soil moisture and soil temperature sensors were placed at depths of $0.05,0.1$, $0.2,0.5$ and $1 \mathrm{~m}$. Soil heat flux plates (two per plot) were installed at $0.1 \mathrm{~m}$ and the remaining sensors were mounted at $4 \mathrm{~m}$. The height of the eddy covariance system was changed over time in order to keep the sensors close to the vegetation and minimize the situations when the footprint, the area measured by the instrumentation, extended beyond the plot's edge. The minimum height was $2.5 \mathrm{~m}$, and the instruments were always higher than $1.34 h_{\mathrm{c}}$, where $h_{\mathrm{c}}$ is the average plant height, to avoid measuring in the roughness sublayer, the layer just above the vegetation that is strongly affected by individual canopy elements (Raupach, 1994).

Aboveground biomass was measured periodically (before and after the growing season, and monthly throughout the growing season) by clipping all vegetation at ground level in quadrats at 4 randomly located positions within the plot. Quadrats were located in different, non-adjacent locations for each sampling date. In addition, quadrats were $0.45 \times 0.45 \mathrm{~m}$ for switchgrass and prairie and $0.75 \times 0.75 \mathrm{~m}$ for maize and miscanthus (to account for planting row separation). Biomass was dried at $60^{\circ} \mathrm{C}$ for at least $48 \mathrm{~h}$ and weighed. Leaf area index (LAI), representing the total horizontal leaf surface divided by the land area over which that vegetation grows was measured using the LAI-2000 (LI-COR Biosciences, 
Lincoln, NE, USA), an electronic leaf area analyzer which utilizes a nondestructive optically based technique. The nondestructive optical technique is based upon Beer's Law and the relationship of light's changing properties as it is transmitted through the canopy (Jonckheere et al., 2004). Leaf area index was measured weekly during the growing season (from 6 July 2009 to 13 October 2009, and from 28 April 2010 to 28 November 2010) for each species. Within each plot 8 subsamples were measured and later averaged.

\subsection{Flux calculation and quality control}

The turbulent fluxes of heat, water vapor and $\mathrm{CO}_{2}$ were calculated using the eddy covariance technique (Aubinet et al., 2000; Lee et al., 2004). The high frequency data were processed using the software Alteddy ${ }^{1}$ (Jan Elbers, Alterra Group, Wegeningen, The Netherlands). A double rotation scheme was used to align the coordinate system to the main wind direction and make the average vertical velocity zero (Kaimal and Finnigan, 1994). The effects of humidity on the temperature measured by the sonic anemometer were corrected according to Schotanus et al. (1983) and the effects of air density on the data from the infrared has analyzer were corrected after Webb et al. (1980, WPL correction). The software also corrected the fluxes for losses in the high frequency part of the spectrum, caused by sensor separation (Moore, 1986). The quality of each half-hour average was estimated according to Foken et al. (2004), which suggested the use of flags to classify the fluxes according to the level of non-stationarity (e.g., flag 3 corresponds to $50 \%$ of non-stationarity).

During periods of low turbulence $\mathrm{CO}_{2}$ accumulates below the measurement height and is not accounted by the eddy covariance system. To account for that missing flux, the $\mathrm{CO}_{2}$ storage flux $\left(F_{\mathrm{S}}\right)$ was calculated as in Aubinet et al. (2001):

$F_{\mathrm{s}}=\frac{P_{\mathrm{air}}}{R T_{\mathrm{air}}} \frac{\Delta C}{\Delta t} h$

where $P_{\text {air }}$ is the air pressure, $R$ is the molar gas constant, $T_{\text {air }}$ is the air temperature, $\Delta C$ is the change in $\mathrm{CO}_{2}$ concentration over the time interval $\Delta t$, and $h$ is the measurement height. The eddy covariance $\mathrm{CO}_{2}$-flux, when integrated with the $\mathrm{CO}_{2}$ storage change, is referred to the net ecosystem exchange (NEE).

The energy balance closure consists of comparing several energy terms to the available energy measured as net radiation $\left(R_{\mathrm{n}}\right)$. In general, the sensible heat flux $(H)$, the latent heat flux $(L E)$ and the soil heat flux $(G)$ are summed and plotted against $R_{\mathrm{n}}$. The result obtained in several ecosystems is an imbalance of approximately 20\% (Twine et al., 2000; Wilson et al., 2002; Foken et al., 2006). Meyers and Hollinger (2004), measuring over soybean and maize in a nearby site (Bondville, IL), included some heat storage terms in their calculation and improved the closure to approximately $10 \%$. In this work, we used the expressions from Meyers and Hollinger (2004) to calculate the soil heat storage change and the storage as photosynthesis. The heat storage in the soil layer $\Delta z$ was calculated as:

$S_{\mathrm{g}}=\frac{\Delta \Theta\left(\theta_{\mathrm{w}} m_{\mathrm{sw}} c_{\mathrm{w}}+\rho_{\mathrm{s}} c_{\mathrm{s}}\right) \Delta z}{\Delta t}$

where $\Delta \Theta$ is the change in temperature at $5 \mathrm{~cm}$ calculated over the period $\Delta t, \theta_{\mathrm{w}}$ is the volumetric water content at $5 \mathrm{~cm}, m_{\mathrm{sw}}$ is the density of water, $c_{\mathrm{w}}$ is the specific heat capacity of plant water, $\rho_{\mathrm{s}}$ is the soil bulk density and $c_{\mathrm{s}}$ is the specific heat capacity of soil. The energy stored as photosynthesis $\left(S_{\mathrm{ph}}\right)$ was calculated using the conversion of $28 \mathrm{~W} \mathrm{~m}^{-2}$ for each $56.7 \mu \mathrm{mol} \mathrm{m}^{-2} \mathrm{~s}^{-1}$ (Nobel, 1974).

\footnotetext{
1 http://www.climatexchange.nl/projects/alteddy/index.htm.
}

Quality control consisted of first checking the data for values that were outside a reasonable range, e.g. $-70<\mathrm{CO}_{2}$-flux $<30 \mu \mathrm{mol} \mathrm{m}^{-2} \mathrm{~s}^{-1}, \quad-20<L E<600 \mathrm{~W} \mathrm{~m}^{-2}$, $-100<H<300 \mathrm{Wm}^{-2},-40<T_{\mathrm{air}}<50^{\circ} \mathrm{C}$ and $0<S_{\text {in }}<1500 \mathrm{~W} \mathrm{~m}^{-2}$, where $S_{\text {in }}$ is the short-wave incoming radiation. Next, an algorithm that employed a moving window of 200 records was used to remove spikes, defined as values inside the window that exceeded the mean \pm 3.5 standard deviations. This process was repeated three times before the window moved 100 records forward in the time series. Besides the flags used to quantify the quality of fluxes, the footprint analysis was also used to flag cases when the fluxes corresponded to an area outside the edges of each plot. The footprint model used in this work was the one developed by Hsieh et al. (2000), which was validated by measurements performed by the authors over an irrigated potato field. Here, the model was used to calculate the distance where the cumulative flux reached $70 \%$ of the total, for each half-hour flux. If this distance exceeded the plot's edges, the data were removed.

Continuous time series of fluxes and other meteorological variables are needed if one is interested in calculating cumulative fluxes over a certain period of time. However, instrument malfunction, rain events, footprint exceeding the plot area and other factors introduce gaps in the fluxes and other variables. Gap-filling of time series was performed according to the methods described in Zeri and Sá (2010). In short, gaps of up to $1 \mathrm{~h}$ were filled using a cubic interpolation method. Longer gaps were filled by searching for data measured at the same time of day and under similar environmental conditions, in adjacent days. In addition to screening of bad data based on the quality control, the friction velocity, $u_{*}$, was used to flag situations with low levels of turbulence, which are not suitable for the eddy covariance method (Aubinet et al., 2000; Falge et al., 2001). For this work the threshold for $u_{*}$ was determined to be $0.1 \mathrm{~m} \mathrm{~s}^{-1}$. The estimation of uncertainty caused by random errors or errors associated with data gaps was based on the methodology of Richardson and Hollinger (2007), which consisted of adding noise and random artificial gaps to the original data and applying the gapfilling algorithm. The process was repeated 50 times and the errors were calculated as the standard deviation of all cumulative fluxes generated.

A flux partitioning method (Reichstein et al., 2005; Zeri and Sá, $2010)$ was used to separate NEE into ecosystem respiration $\left(R_{\text {eco }}\right)$ and gross primary production (GPP). Gross primary production was calculated as GPP $=\mathrm{NEP}-R_{\mathrm{eco}}$, where $\mathrm{NEP}=-\mathrm{NEE}$ (the sign convention for NEE is such that negative indicates net carbon uptake). Ecosystem respiration was determined by applying a regression model (Lloyd and Taylor, 1994) to nighttime fluxes measured during turbulent conditions:

$R_{\text {eco }}=R_{\text {ref }} e^{E_{0}\left[\left(1 / T_{\text {ref }}-T_{0}\right)-\left(1 / T-T_{0}\right)\right]}$

where $R_{\mathrm{ref}}$ is the respiration at the reference temperature $T_{\mathrm{ref}}, E_{0}$ is the activation energy, $T_{0}$ is a constant and $T$ is the air temperature. The reference temperature was set to $283.15 \mathrm{~K}\left(10^{\circ} \mathrm{C}\right)$ and $T_{0}$ was set to $227.13 \mathrm{~K}$, as in Lloyd and Taylor (1994). The activation energy $E_{0}$ and $R_{\text {ref }}$ were determined using a non-linear least-squares regression method.

\subsection{Carbon budget calculations}

Net ecosystem carbon balance (NECB) was calculated for two periods: 1 April 2009-31 March 2010 and from 1 April 2010 to 31 March 2011. NECB differs from NEE in that it includes removal of carbon through harvest. In the case of maize and soybean, we computed NECB by subtracting carbon removed in the harvested grain (residue was left of the field). For all crops, NECB values would reflect changes in non-harvestable carbon pools: soil organic carbon, root biomass, and aboveground or buried (i.e., through 
plowing) litter, and un-harvested standing aboveground biomass (perennial grasses only). These components of the ecosystem carbon budget will be discussed in a future publication.

\section{Results and discussion}

\subsection{Micrometeorological and biometric measurements}

We consider data from June of 2008 to December of 2010. Air temperature $\left(T_{\text {air }}\right)$ ranged from approximately $-20^{\circ} \mathrm{C}$, in January of 2009, to $30^{\circ} \mathrm{C}$, from June to August of 2008 and 2009 (Fig. 1a). The median value of vapor pressure deficit (VPD, Fig. 1b) between July and October 2008 was $4.8 \mathrm{~h} \mathrm{~Pa}$, which was significantly higher (at the $5 \%$ level) than the median value of $3.1 \mathrm{~h}$ Pa for the same period in 2009. Shortwave incoming radiation $\left(S_{\text {in }}\right)$ varied seasonally and with cloud cover (Fig. 1c), and rainfall events (Fig. 1d) became more frequent and intense around July 2009.

During the second growing season (2009), as switchgrass and prairie crops were becoming relatively well-established, phenological differences between perennial grasses and maize became evident (Fig. 2). Maize exhibited characteristic phenology, with both LAI and biomass increasing rapidly during June and July and remaining high through mid-September, at which point LAI declines as the leaves begin to dry out and drop. While the average LAI of the perennials did not differ dramatically from that of maize and soy, a couple of meaningful differences were evident. First, perennials generally had higher LAI and biomass than maize at the beginning of the growing season, having begun their growth before the planting of maize or soy. This difference in phenology-along with continued growth later into the season-has been observed before and represents one of the advantages of perennial grasses over traditional row crop agriculture (Heaton et al., 2008; Dohleman, 2009). Second, whereas LAI's did not differ dramatically, maize attained a peak aboveground biomass that was twice that of the perennial grasses in 2009, while the perennials had higher biomass than soy in 2010. As these crops were not yet mature, it remains to be seen how the peak biomass of mature perennial grass crops will compare to that of maize. Previous research in a nearby location has shown that full-grown miscanthus maintains higher biomass than maize throughout the entire growing season (Dohleman, 2009).

The LAI and aboveground biomass of miscanthus were generally lower than that of the other species throughout almost the entire growing season. Toward the end of the growing season (September and October), miscanthus LAI and biomass increased significantly, reaching seasonal maxima in October when the LAI of other crops was already in decline. This phenology is consistent with previous research in Illinois showing that miscanthus biomass peaks in September or October (Dohleman, 2009); however, the low LAI and biomass of miscanthus relative to maize and switchgrass was unusual, as other studies have shown that miscanthus consistently out-yields both switchgrass and maize across the state of Illinois (Heaton et al., 2008; Dohleman, 2009). This result was attributable to poor establishment during the first year because of relatively late planting, dry conditions during the second half of 2008 when the rhizomes were planted (Fig. 1d), and rhizome mortality during the cold spell of January 2009.

\subsection{Energy balance closure}

The balance between the inputs and outputs of energy at the ecosystem scale is an important test for the eddy covariance technique (Wilson et al., 2002; Foken et al., 2006). Some authors found a relationship between imbalance of the energy closure and underestimation of fluxes of $\mathrm{CO}_{2}$, suggesting that energy closure could be important to accurately quantifying the carbon balance of an ecosystem (Twine et al., 2000; Wilson et al., 2002). Here, we characterize the energy balance using data from both the micrometeorological measurements $\left(R_{\mathrm{n}}\right.$, soil heat flux and storage terms) and the eddy covariance system ( $H$ and $L E)$. The period of data used ranged from 1 July 2010 to 31 August 2010, and the average daily cycles for each component are shown in Fig. 3. The data was filtered so that only high quality fluxes of $H$ and $L E$ were used. The quality criteria was based on stationarity of fluxes, according to the methodology defined in Foken et al. (2004).

The fraction of the available energy $R_{\mathrm{n}}$ captured by all the fluxes and storage terms ranged from 0.84 , for switchgrass, to 0.89 , for miscanthus (Fig. 4). Both values are within the range reported in other studies (Wilson et al., 2002), indicating that our measurements are satisfactorily capturing the energy fluxes and storages of heat. The lower closure for switchgrass was caused by lower values of heat storage in the soil $\left(S_{\mathrm{g}}\right.$, Fig. 3c). While the measurements of net radiation, sensible and latent heat fluxes correspond to a large area around the tower, heat storage in the topsoil layer is calculated using single-point measurements - in this case, soil temperature $\left(T_{\text {soil }}\right)$ and moisture. The comparison of soil temperature between plots (not shown) revealed that the median $T_{\text {soil }}$ in switchgrass was approximately $4{ }^{\circ} \mathrm{C}$ lower compared to miscanthus (difference statistically different at the $5 \%$ level), indicating that this probe, which was supposed to be at $5 \mathrm{~cm}$ below the surface, was most likely placed in a deeper level compared to the other plots. Since the fluctuations in temperature are smaller deeper in the soil, the resulting heat storage, which is calculated using differences from period to period, will also be smaller.

To test the contribution of heat storage in the soil to the energy balance closure, we used the storage measured at the maize/soybean plot in the energy balance for switchgrass and miscanthus, which had the lowest and highest amplitudes of $S_{\mathrm{g}}$, respectively. The storage measured in maize/soybean had an intermediate value, which was suitable to this test. As a result, the closure increased for switchgrass (from 0.84 to 0.90 ) and decreased for miscanthus (from 0.89 to 0.79 ), suggesting that measurements of $S_{\mathrm{g}}$ were underestimated for switchgrass and overestimated in miscanthus (assuming that $S_{\mathrm{g}}$ in maize/soybean was unbiased). In spite of the differences in energy balance closure, the values reported here are satisfactory considering the typical closure of $80 \%$ found in other sites (Wilson et al., 2002). The energy balance closure could be further improved if the storage of heat in the biomass was included (Meyers and Hollinger, 2004) or if the influence of low frequency contributions to turbulent fluxes was investigated (Sakai et al., 2001). In addition, when comparing the differences in closure between plots we assumed that $S_{\text {g }}$ measured in maize/soy bean was unbiased and represented the true heat storage in the soil. To decrease the uncertainty regarding this assumption, additional measurements of soil variables (temperature and moisture) would have to be done in more locations over the plots, but this detailed investigation would go beyond the scope of this paper.

\subsection{Annual fluxes of $\mathrm{CO}_{2}$}

Daily and seasonal patterns of net ecosystem exchange of $\mathrm{CO}_{2}$ differed across the four agroecosystems (Fig. 5). First, crops differed in maximum rates of carbon uptake. Maize had the highest rates of carbon uptake (blue colors)-particularly during the 2008 growing season-followed by switchgrass, prairie and miscanthus, respectively. This is consistent with previous work that has shown that maximum rates of photosynthesis in maize leaves exceed those of miscanthus during the peak growing season (Dohleman, 2009).

Second, phenology differed among crops. In 2008, initiation of growth was limited by planting time. Miscanthus was planted last, and net carbon uptake did not begin until midsummer, resulting 

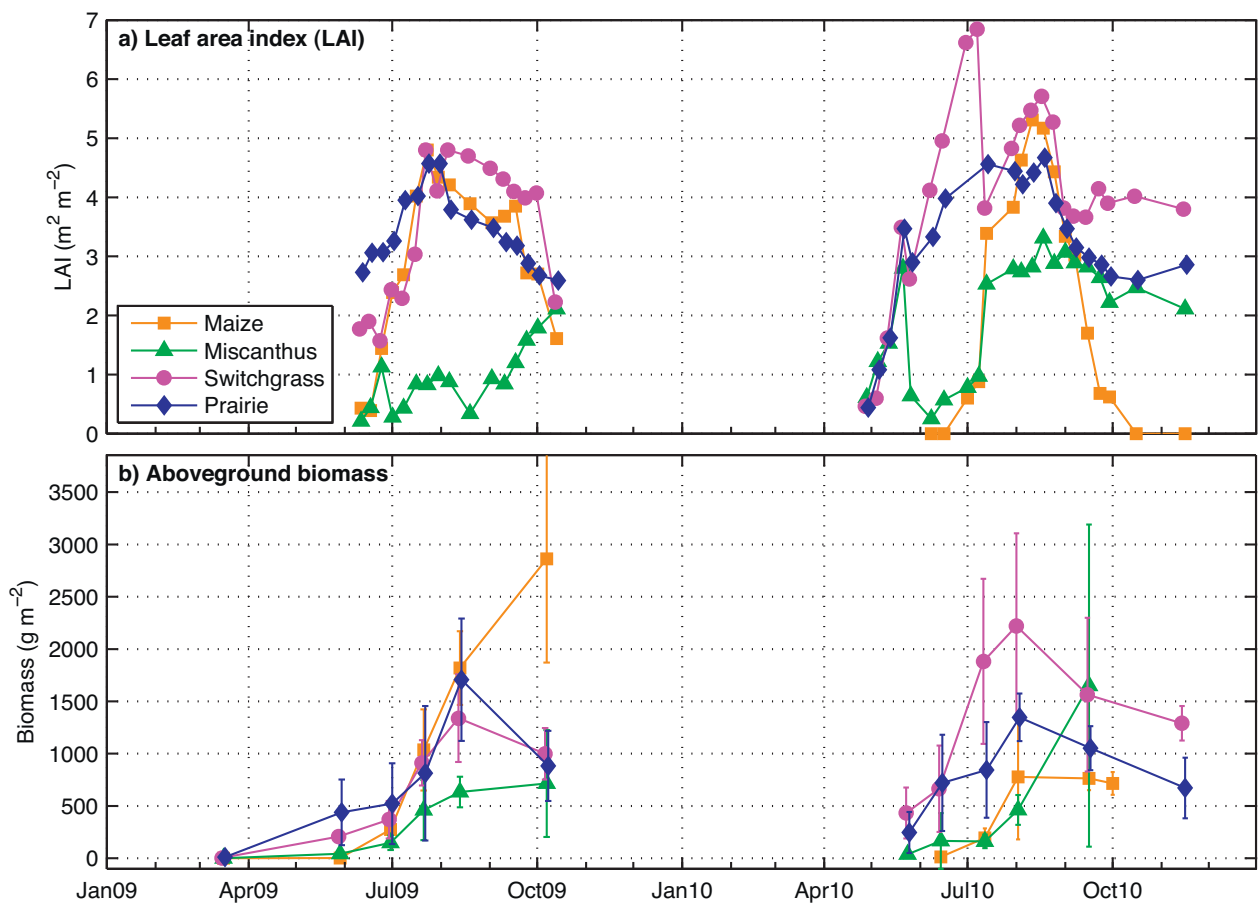

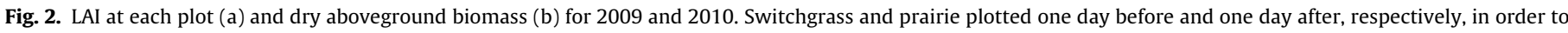
minimize overlapping of symbols.

in the lowest annual net uptake among the four species (values shown in Fig. 5). The growing season was longer for the perennial grasses (miscanthus, switchgrass, and prairie) than for maize $(2008,2009)$ or soybean $(2010)$, with net uptake of carbon
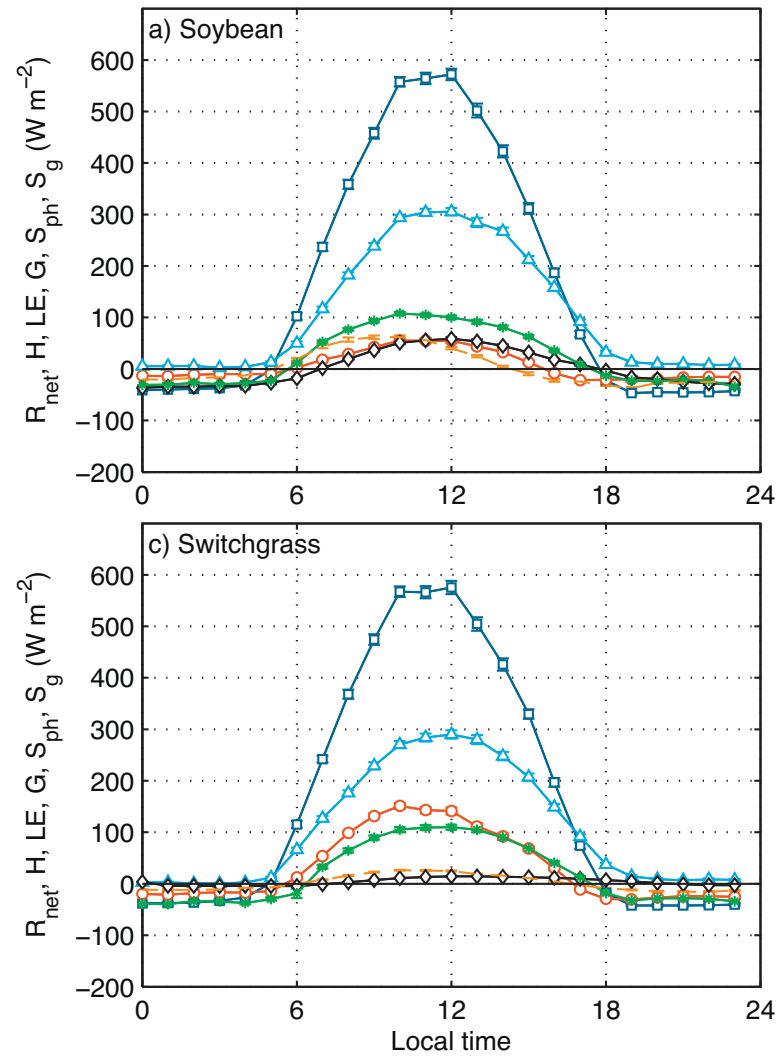

beginning around June and lasting until November. In 2009 and 2010 , the perennial grasses began taking up carbon $\approx 1$ month before maize, and continued somewhat longer into the fall. The observed longer growing season of the perennial grasses is
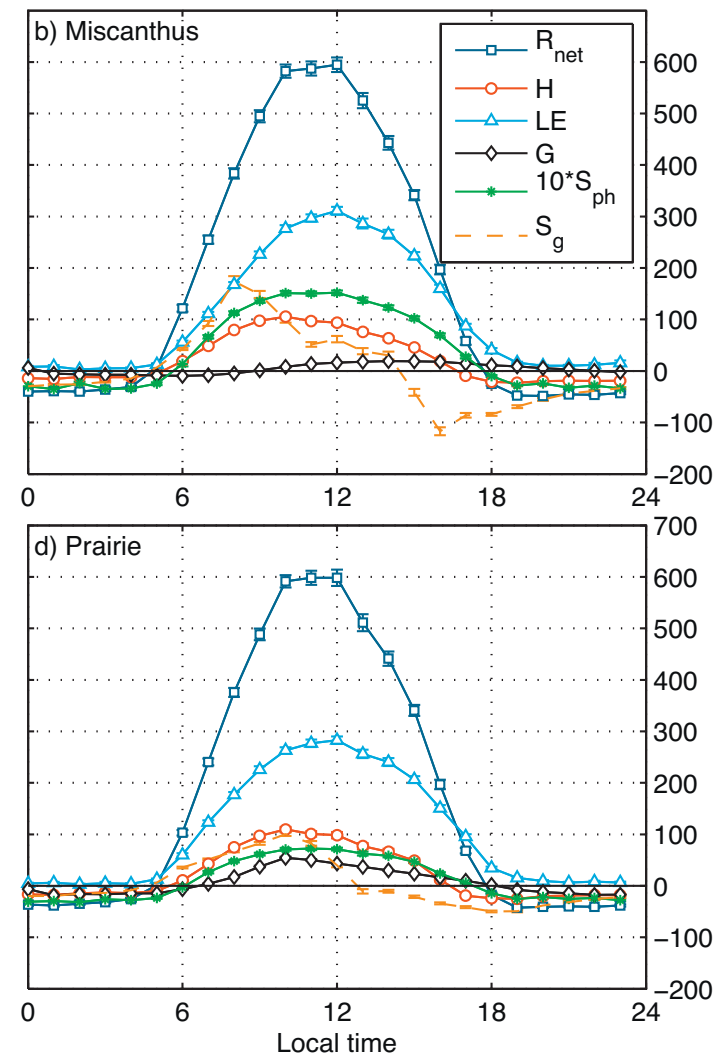

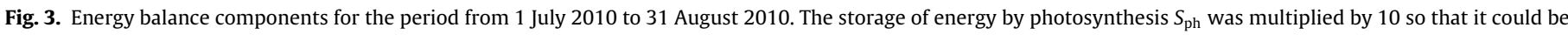
displayed in the same scale as the other terms. 

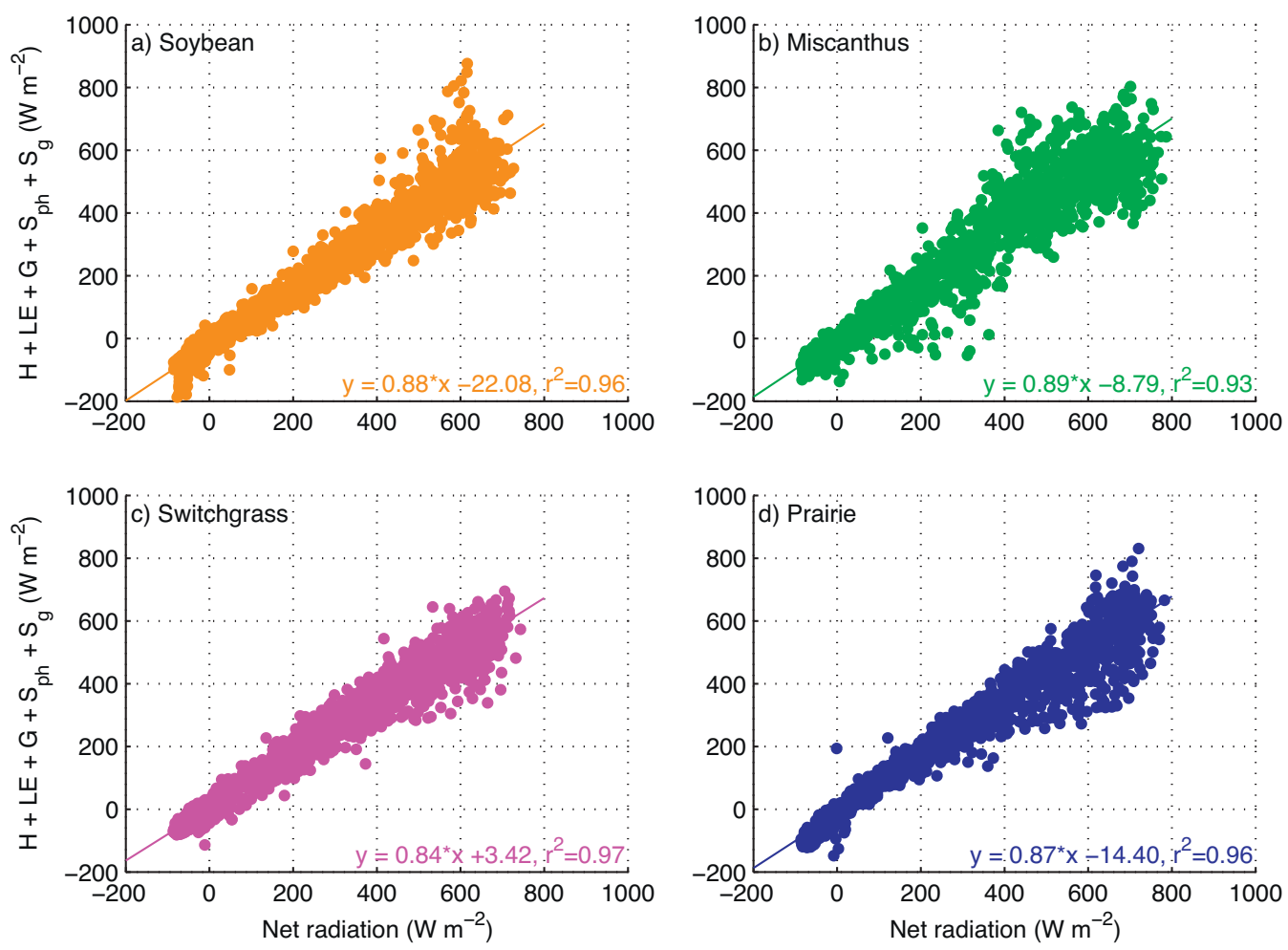

Fig. 4. Energy balance closure for the period from 1 July 2010 to 31 August 2010.

consistent both with our biometric phenological data (Section 3.1 and Fig. 2) and with previous work in Illinois showing that the period over which photosynthesis occurs is substantially longer for miscanthus than for maize (Dohleman, 2009).

Net ecosystem exchange integrated over an entire year differed substantially among crops. In 2009, the annual uptake of carbon was highest for switchgrass $\left(-4.53 \pm 0.2 \mathrm{t}_{\mathrm{C}} \mathrm{ha}^{-1}\right)$, followed by prairie $\left(-3.44 \pm 0.2 \mathrm{t}_{\mathrm{C}} \mathrm{ha}^{-1}\right)$. This was not surprising, given that switchgrass and the native prairie mix exhibited excellent establishment and survivorship from the first to the second year. In spite of the problems with the establishment of miscanthus (winter die-off of rhizomes), its annual uptake in $2009(-2.81 \pm 0.3$ $\mathrm{t}_{\mathrm{C}} \mathrm{ha}^{-1}$ ) was similar to the net uptake obtained for the maize $\left(-3.07 \pm 0.4 \mathrm{t}_{\mathrm{C}} \mathrm{ha}^{-1}\right)$, suggesting that even a poorly established miscanthus crop may rival traditional row-crop agriculture in terms of carbon sequestration. Due to poor establishment, miscanthus was replanted in May of 2010. In spite of that, its cumulative NEE $\left(-5.54 \pm 0.2 \mathrm{t}_{\mathrm{C}} \mathrm{ha}^{-1}\right)$ was the highest in 2010 , compared to the other plots. The annual NEE improved in 2010 for switchgrass $\left(-4.85 \pm 0.2 \mathrm{t}_{\mathrm{C}} \mathrm{ha}^{-1}\right)$ and remained approximately constant for native prairie $\left(-2.95 \pm 0.3 \mathrm{t}_{\mathrm{C}} \mathrm{ha}^{-1}\right)$, suggesting that switchgrass might still be in the establishment phase while the annual uptake of native prairie reached a constant level.

Several interesting features become evident when fluxes were plotted as cumulative sums to visualize the temporal evolution of NEE, gross primary production and ecosystem respiration (Fig. 6). Mowing weeds in switchgrass and prairie plots during the first year affected cumulative NEE (dashed lines in Fig. 6a), decreasing the rate of net carbon uptake for several days. Whereas maize took up far more carbon than the perennial grass crops during the 2008 measurement period, perennial grasses rivaled or exceeded corn and soy in the following years. This was largely because they become net carbon sinks early in the growing season while the maize agroecosystem lost carbon through soil respiration (Fig. 6c) before crop establishment and did not become a sink until July.
Moreover, switchgrass and miscanthus remained more-or-less carbon neutral through the end of the year, whereas maize became a net carbon source starting in September. Maize and switchgrass had a similar cumulative GPP at the end of 2009 (Fig. 6b), but the higher cumulative $R_{\text {eco }}$ for maize resulted in a smaller annual NEE for that year (Fig. 6a).

In 2010, $\mathrm{CO}_{2}$ exchange in switchgrass and native prairie followed a similar pattern as in 2009, with cumulative NEE becoming negative (sink) around May and net accumulation ceasing in middle August (senescence). Soybean was not planted until 25 May 2010, and net accumulation of carbon started in middle June and ended at the end of August. Miscanthus was replanted in May of 2010, which contributed to delay the net accumulation of carbon, in comparison with switchgrass and prairie. In spite of that, the cumulative GPP of miscanthus at the end of 2010 was higher compared to the value for native prairie and, in combination with a lower ecosystem respiration, resulted in a stronger sink of carbon for miscanthus compared to native prairie. The perennial grasses-particularly switchgrass and prairie-had higher ecosystem respiration than soy. Higher aboveground biomass (Fig. 2b) may contribute to this difference.

\subsection{Net ecosystem carbon balance}

Net ecosystem carbon balance (NECB) is the carbon balance at the plot scale, i.e., the comparison between the net carbon uptake from plants with the carbon exported as harvested biomass or grain (Chapin et al., 2006). To investigate the evolution of NECB since the beginning of measurements, the grain and biomass harvests were added to cumulative NEE (Fig. 6a), resulting in the cumulative carbon balance (Fig. 7). The harvests move the cumulative NEE up, reducing the long-term uptake. The net carbon uptake of maize shifts the balance toward a sink, but the harvests remove a large amount of carbon, offsetting the sink. 

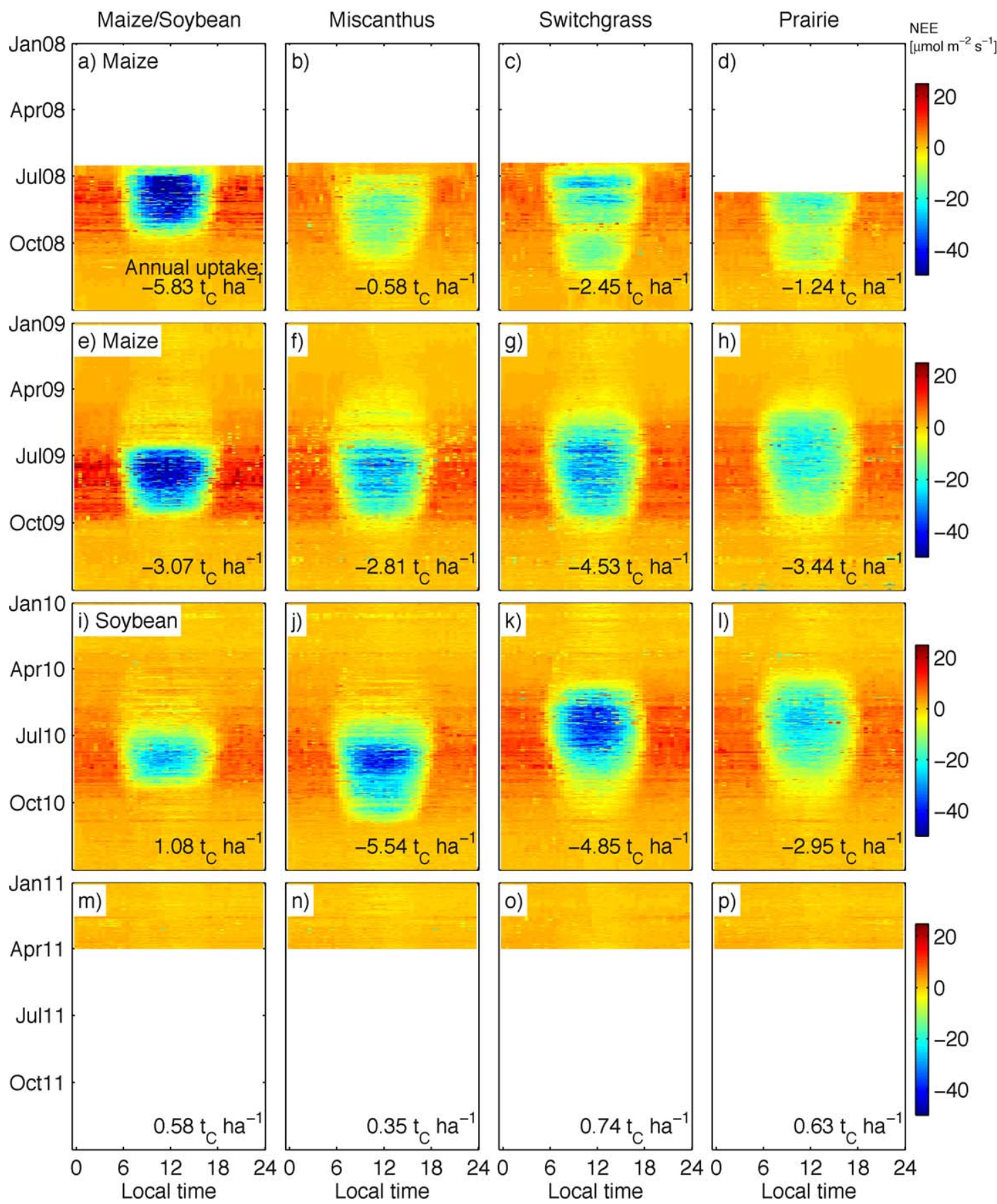

Fig. 5. Fingerprint plots of gap-filled NEE of $\mathrm{CO}_{2}$ for the period 2008 to April 2011.

The long-term carbon balance for the grasses was negative, i.e., a sink of carbon. The annual uptake of carbon by the miscanthus plot has been increasing since 2008, even though this plot had to be replanted due to poor establishment. The harvests performed at this plot in 2010 and in 2011 removed less biomass compared to the harvests in other plots, contributing to a long-term sink of carbon at the miscanthus plot $\left(\sim 6 \mathrm{t}_{\mathrm{C}} \mathrm{ha}^{-1}\right)$. Switchgrass and prairie were harvested twice in 2010 but the long-term carbon balance was still negative.

Cumulative NECB was calculated for two one-year periods of measurements: 1 April 2009-31 March 2010 and from 1 April 2010 to 31 March 2011 (Fig. 8). The maize/soybean plot was a source of carbon in the first two years of measurements while the grasses were sinks. The sink of carbon by miscanthus increased from the first period to the second due to the small amount of harvested material in those periods. Switchgrass had a lower net sink of carbon in the second period, while the carbon balance for native prairie in the second period was close to zero, implying that the harvested biomass matched the net carbon accumulation. Additional years of measurements are required to determine whether switchgrass and prairie will have a carbon balance close to neutral after several growing seasons. Future work assessing the belowground carbon cycle will help to complete the picture on carbon flows within these ecosystems.

These results demonstrate that perennial grass biofuel crops act as a carbon sink during their establishment phase. This is consistent with previous research showing that perennial grass bioenergy crops can act as a net sink of carbon-at least during the initial 


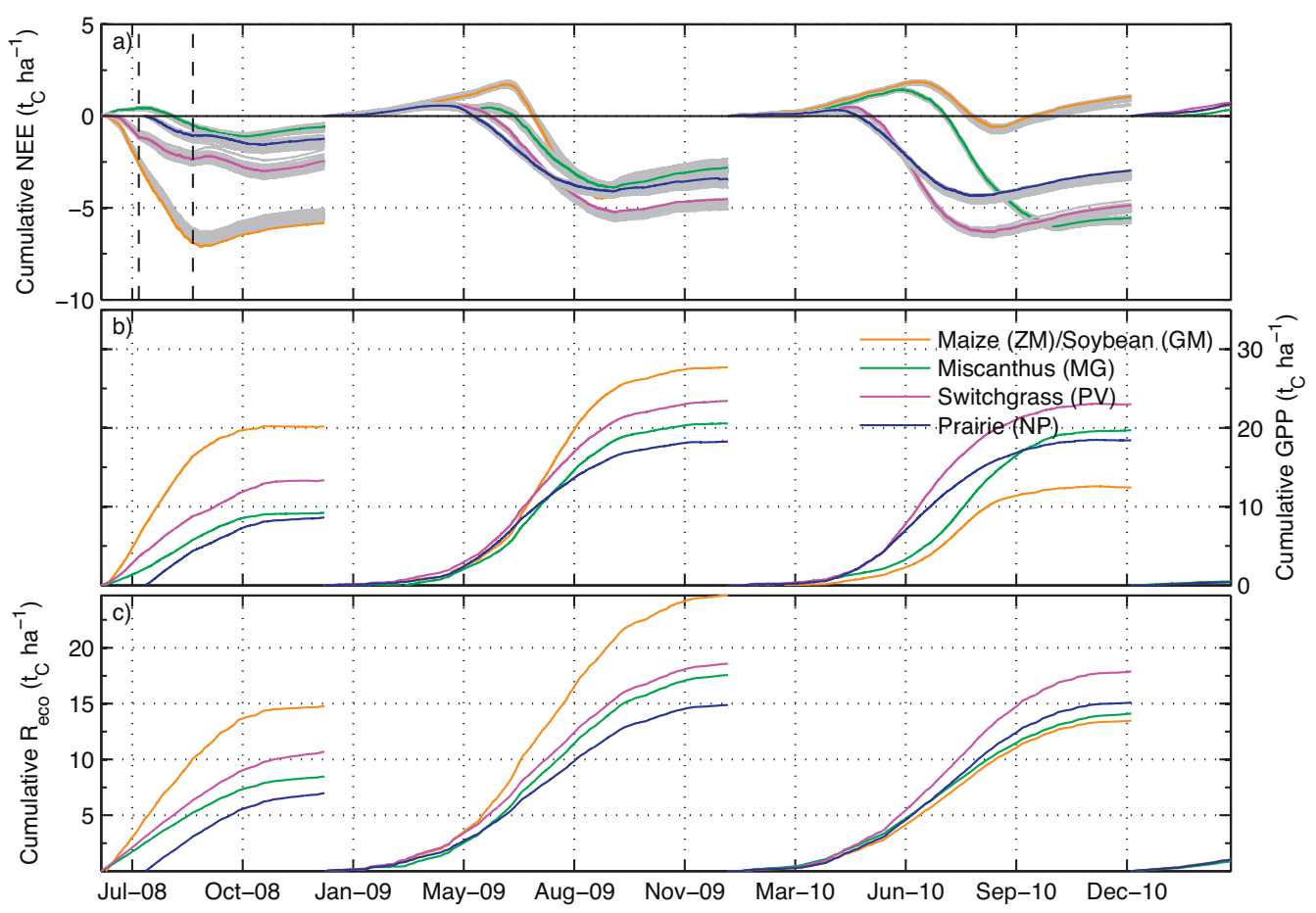

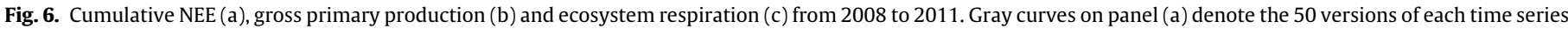

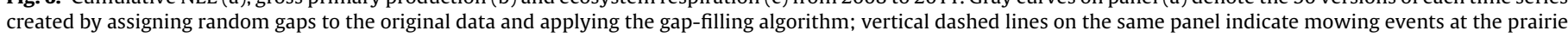
and switchgrass plots.

establishment phase (Skinner and Adler, 2010). In this study, the native species-switchgrass and prairie-established well and had higher harvestable biomass than miscanthus. Native species have the advantage of being adapted to the local climate and having resources to fight pests and diseases typical to the region. This-in combination with the method of planting (seeded, as opposed to planting of rhizomes)-may have allowed for better establishment of these crops, illustrating one advantage of switchgrass and
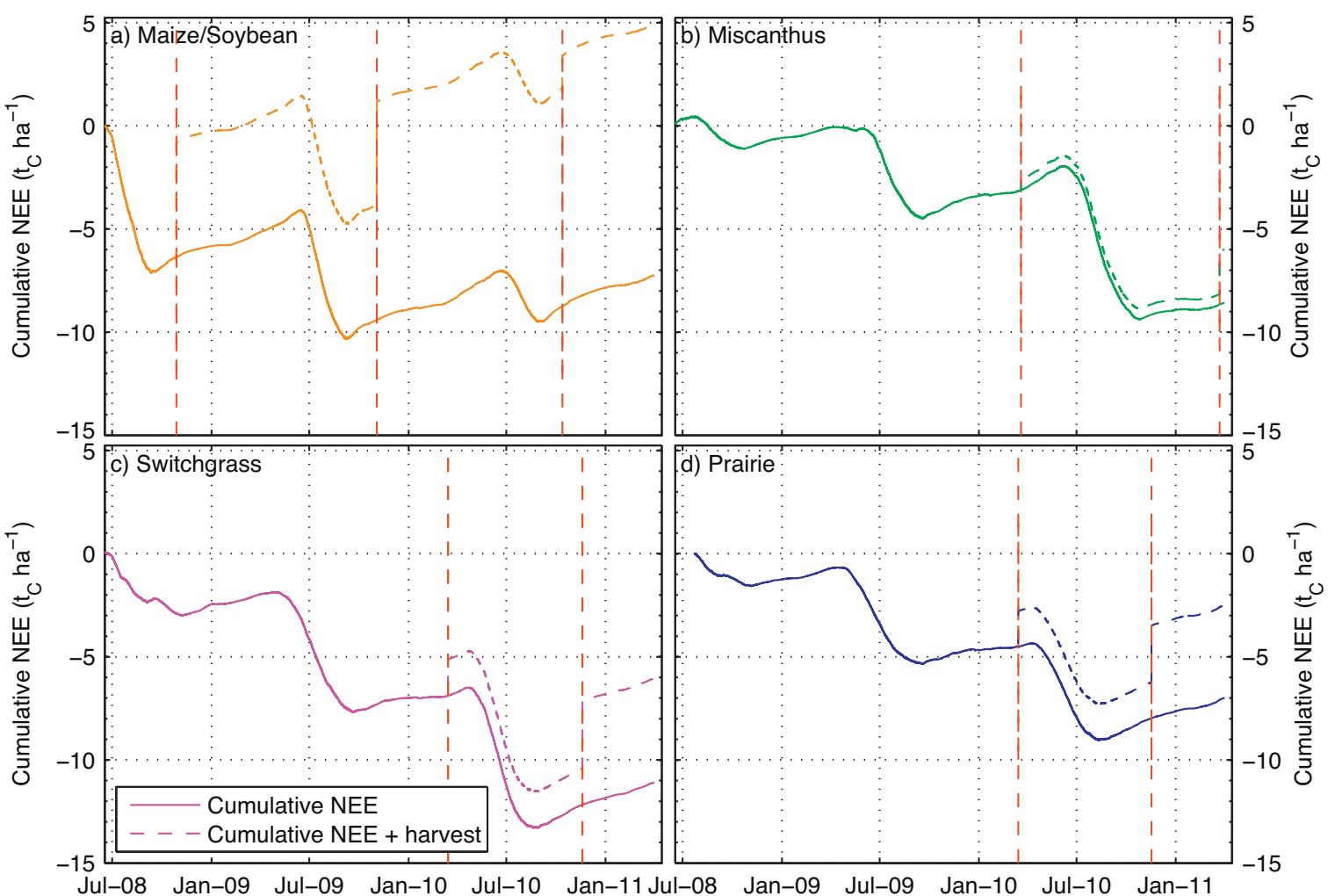

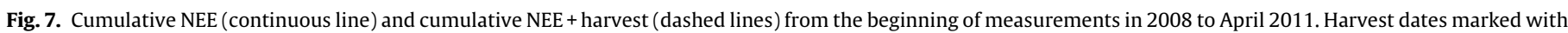
vertical dashed lines. 


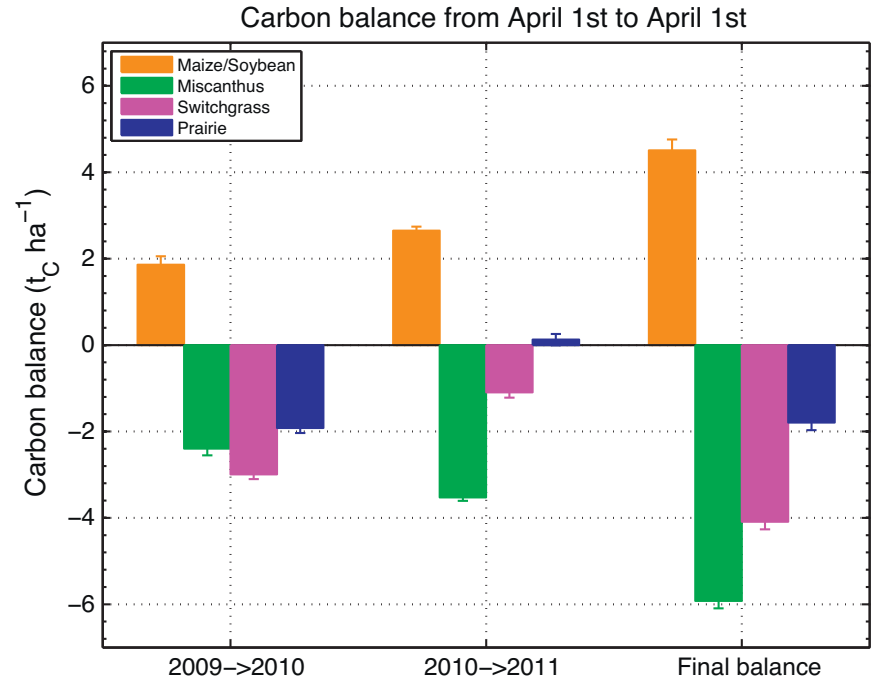

Fig. 8. Net ecosystem carbon balance for all plots.

native prairie that counteracts their lower potential yields when compared to established plots of miscanthus (Heaton et al., 2008; Dohleman et al., 2009; Davis et al., 2010). Miscanthus is a promising alternative to maize for biofuel production because of its high productivity and the fact that it does not require fertilization (Heaton et al., 2004). Our measurements showed that miscanthus was a sink of carbon during the first 2.5 years of establishment, but the lower amount of harvested biomass was determinant to that balance. Continuous measurements are required to verify if the long-term carbon balance of miscanthus, switchgrass and native prairie will be a sink, a source or neutral regarding the carbon cycle.

\section{Conclusions}

We investigated energy balance closure and the carbon balance over three perennial grass crops and a row crop control in Central Illinois, USA to better understand the potential climate impacts of widespread deployment of perennial grass bioenergy crops. The energy balance closure varied from $84 \%$ to $89 \%$, supporting the accuracy of our measurements. Whereas maize had the highest maximal carbon uptake rates, the perennial grasses had significantly extended growing seasons, such that their total carbon uptake rivaled that of corn in the second growing season and greatly exceeded that of soy in the third growing season. The net ecosystem carbon balance, which accounts for harvested biomass and grain, revealed that at the end of 2.5 years of establishment the grasses were a sink of carbon whereas the maize/soybean plot was a net source of carbon to the atmosphere. However, when NECB was separated into two full years of measurements, it was revealed that the sink of carbon of switchgrass and prairie was reduced in the second year due to the cumulative impact of two harvests. Continuous measurements over the next years are required in order to determine whether miscanthus, switchgrass and prairie can sustain a long-term sink of carbon if managed for biofuels, i.e., if harvested annually.

\section{Acknowledgements}

Climate data provided by the Illinois State Water Survey (ISWS) located in Champaign, Peoria, and Carbondale, Illinois, and on the web at www.isws.illinois.edu. The authors are grateful to several people that helped with fieldwork: Christina Burke, Sarah Campbell, David Drag, Andy VanLoocke, Micah Sweeney, Chris Novotny, Owen Cofie, James Lee, Bradley Danner, Nicholas DeLucia, Michael
DeLucia, Jeremy Pillow, Lauren Segal, and Abhishek Pal. We are also grateful to the Energy Farm crew: Tim Mies, Chris Rudisill, Drew Schlumpf and Emily Doherty. We thank Dr. Saber Miresmailli for the preparation of Table 1. This work was funded by the Energy Biosciences Institute.

\section{References}

Adler, P.R., Del Grosso, S.J., Parton, W.J., 2007. Life-cycle assessment of net greenhouse-gas flux for bioenergy cropping systems. Ecol. Appl. 17, 675-691.

Anderson-Teixeira, K.J., Davis, S., Masters, M., Delucia, E., 2009. Changes in soil organic carbon under biofuel crops. Global Change Biol. Bioenerg. 1, 75-96.

Aubinet, M., Chermanne, B., Vandenhaute, M., Longdoz, B., Yernaux, M., Laitat, E., 2001. Long term carbon dioxide exchange above a mixed forest in the Belgian Ardennes. Agric. For. Meteorol. 108, 293-315.

Aubinet, M., Grelle, A., Ibrom, A., Rannik, U., Moncrieff, J., Foken, T., Kowalski, A.S. Martin, P.H., Berbigier, P., Bernhofer, C., Clement, R., Elbers, J., Granier, A., Grunwald, T., Morgenstern, K., Pilegaard, K., Rebmann, C., Snijders, W., Valentini, R., Vesala, T., 2000. Estimates of the annual net carbon and water exchange of forests: the EUROFLUX methodology. Adv. Ecol. Res. 30, 113-175.

Chapin, F., Woodwell, G., Randerson, J., Rastetter, E., Lovett, G., Baldocchi, D., Clark D., Harmon, M., Schimel, D., Valentini, R., Wirth, C., Aber, J., Cole, J., Goulden, M., Harden, J., Heimann, M., Howarth, R., Matson, P., McGuire, A., Melillo, J., Mooney, H., Neff, J., Houghton, R., Pace, M., Ryan, M., Running, S., Sala, O., Schlesinger, W., Schulze, E.D., 2006. Reconciling carbon-cycle concepts, terminology, and methods. Ecosystems 9, 1041-1050.

Davis, S., Parton, W., Dohleman, F., Smith, C., Grosso, S., Kent, A., DeLucia, E., 2010 Comparative biogeochemical cycles of bioenergy crops reveal nitrogen-fixation and low greenhouse gas emissions in a Miscanthus $\times$ giganteus agro-ecosystem. Ecosystems 13, 144-156.

Dohleman, F.G., 2009. Seasonal dynamics of productivity and photosynthesis of three biofuel feedstocs: field comparisons of Miscanthus $\times$ giganteus, Panicum virgatum and Zea mays. In: Plant Biology. University of Illinois, Urbana, Champaign.

Dohleman, F.G., Heaton, E.A., Leakey, A.D.B., Long, S.P., 2009. Does greater leaflevel photosynthesis explain the larger solar energy conversion efficiency of Miscanthus relative to switchgrass? Plant Cell Environ. 32, 1525-1537.

Falge, E., Baldocchi, D., Olson, R., Anthoni, P., Aubinet, M., Bernhofer, C., Burba, G., Ceulemans, G., Clement, R., Dolman, H., Granier, A., Gross, P., Grunwald, T. Hollinger, D., Jensen, N.O., Katul, G., Keronen, P., Kowalski, A., Lai, C.T., Law, B.E., Meyers, T., Moncrieff, J., Moors, E., Munger, J.W., Pilegaard, K., Rannik, U., Rebmann, C., Suyker, A., Tenhunen, J., Tu, K., Verma, S., Vesala, T., Wilson, K., Wofsy, S., 2001. Gap filling strategies for long term energy flux data sets. Agric. For. Meteorol. 107, 71-77.

Foken, T., Goeckede, M., Mauder, M., Mahrt, L., Amiro, B.D., Munger, J.W., 2004. Postfield data quality control. In: Lee, X., Massman, W.J., Law, B. (Eds.), Handbook of Micrometeorology: A Guide for Surface Flux Measurement and Analysis. Kluwer Academic Publishers, p. 250.

Foken, T., Wimmer, F., Mauder, M., Thomas, C., Liebethal, C., 2006. Some aspects of the energy balance closure problem. Atmos. Chem. Phys. 6, 4395-4402.

Fortman, J.L., Chhabra, S., Mukhopadhyay, A., Chou, H., Lee, T.S., Steen, E., Keasling, J.D., 2008. Biofuel alternatives to ethanol: pumping the microbial well. Trends Biotechnol. 26, 375-381.

Heaton, E., Dohleman, F.G., Long, S.P., 2008. Meeting US biofuel goals with less land: the potential of Miscanthus. Global Change Biol. 14, 2000-2014.

Heaton, E., Voigt, T., Long, S.P., 2004. A quantitative review comparing the yields of two candidate $C-4$ perennial biomass crops in relation to nitrogen, temperature and water. Biomass Bioenerg. 27, 21-30.

Hill, J., Polasky, S., Nelson, E., Tilman, D., Huo, H., Ludwig, L., Neumann, J., Zheng, H., Bonta, D., 2009. Climate change and health costs of air emissions from biofuels and gasoline. Proc. Natl. Acad. Sci. 106, 2077-2082.

Hsieh, C.I., Katul, G., Chi, T., 2000. An approximate analytical model for footprint estimation of scaler fluxes in thermally stratified atmospheric flows. Adv. Water Resour. 23, 765-772.

Jonckheere, I., Fleck, S., Nackaerts, K., Muys, B., Coppin, P., Weiss, M., Baret, F., 2004 Review of methods for in situ leaf area index determination. Part I. Theories, sensors and hemispherical photography. Agric. For. Meteorol. 121, 19-35.

Jordan, N., Boody, G., Broussard, W., Glover, J.D., Keeney, D., McCown, B.H., McIsaac G., Muller, M., Murray, H., Neal, J., Pansing, C., Turner, R.E., Warner, K., Wyse, D. 2007. Environment - sustainable development of the agricultural bio-economy. Science 316, 1570-1571.

Kaimal, J.C., Finnigan, J.J., 1994. Atmospheric Boundary Layer Flows: Their Structure and Measurement. Oxford University Press, New York.

Lal, R., 2004. Soil carbon sequestration impacts on global climate change and food security. Science 304, 1623-1627.

Lee, X., Massman, W.J., Law, B.E., 2004. Handbook of Micrometeorology: A Guide for Surface Flux Measurement and Analysis. Kluwer Academic, Dordrecht/Boston/London.

Lewandowski, I., Clifton-Brown, J.C., Scurlock, J.M.O., Huisman, W., 2000. Miscanthus: European experience with a novel energy crop. Biomass Bioenerg. 19, 209-227.

Liebig, M., Schmer, M., Vogel, K., Mitchell, R., 2008. Soil carbon storage by switchgrass grown for bioenergy. Bioenerg. Res. 1, 215-222. 
Lloyd, J., Taylor, J.A., 1994. On the temperature-dependence of soil respiration. Funct. Ecol. 8, 315-323.

McIsaac, G.F., David, M.B., Mitchell, C.A., 2010. Miscanthus and switchgrass production in Central Illinois: impacts on hydrology and inorganic nitrogen leaching. J. Environ. Qual. 39, 1790-1799.

McLaughlin, S.B., Adams Kszos, L., 2005. Development of switchgrass (Panicum virgatum) as a bioenergy feedstock in the United States. Biomass Bioenerg. 28, 515-535.

McLaughlin, S.B., Walsh, M.E., 1998. Evaluating environmental consequences of producing herbaceous crops for bioenergy. Biomass Bioenerg. 14, 317-324.

Meyers, T.P., Hollinger, S.E., 2004. An assessment of storage terms in the surface energy balance of maize and soybean. Agric. For. Meteorol. 125, 105-115.

Moore, C.J., 1986. Frequency response corrections for eddy correlation systems. Boundary-Layer Meteorol. 37, 17-35.

Nobel, P., 1974. Introduction to Biophysical Plant Physiology. W.H. Freeman, San Francisco.

NRCS, 2011. Native Prairie: Establishment \& Management of Native Prairie. Natural Resources Conservation Service.

Raupach, M.R., 1994. Simplified expressions for vegetation roughness length and zero-plane displacement as functions of canopy height and area index. Boundary-Layer Meteorol. 71, 211-216.

Reichstein, M., Falge, E., Baldocchi, D., Papale, D., Aubinet, M., Berbigier, P., Bernhofer, C., Buchmann, N., Gilmanov, T., Granier, A., Grunwald, T., Havrankova, K., Ilvesniemi, H., Janous, D., Knohl, A., Laurila, T., Lohila, A., Loustau, D., Matteucci, G., Meyers, T., Miglietta, F., Ourcival, J.M., Pumpanen, J., Rambal, S., Rotenberg, E., Sanz, M., Tenhunen, J., Seufert, G., Vaccari, F., Vesala, T., Yakir, D., Valentini, R., 2005. On the separation of net ecosystem exchange into assimilation and ecosystem respiration: review and improved algorithm. Global Change Biol. 11, 1424-1439.

Richardson, A.D., Hollinger, D.Y., 2007. A method to estimate the additional uncertainty in gap-filled NEE resulting from long gaps in the $\mathrm{CO}_{2}$ flux record. Agric. For. Meteorol. 147, 199-208.

Robertson, G.P., Dale, V.H., Doering, O.C., Hamburg, S.P., Melillo, J.M., Wander, M.M., Parton, W.J., Adler, P.R., Barney, J.N., Cruse, R.M., Duke, C.S., Fearnside, P.M., Follett, R.F., Gibbs, H.K., Goldemberg, J., Mladenoff, D.J., Ojima, D., Palmer, M.W.,
Sharpley, A., Wallace, L., Weathers, K.C., Wiens, J.A., Wilhelm, W.W., 2008. Agriculture - sustainable biofuels redux. Science 322, 49-50.

Sakai, R.K., Fitzjarrald, D.R., Moore, K.E., 2001. Importance of low-frequency contributions to eddy fluxes observed over rough surfaces. J. Appl. Meteorol. 40, 2178-2192.

Schotanus, P., Nieuwstadt, F.T.M., Debruin, H.A.R., 1983. Temperature-measurement with a sonic anemometer and its application to heat and moisture fluxes. Boundary-Layer Meteorol. 26, 81-93.

Skinner, R.H., Adler, P.R., 2010. Carbon dioxide and water fluxes from switchgrass managed for bioenergy production. Agric. Ecosyst. Environ. 138, 257-264.

Somerville, C., Youngs, H., Taylor, C., Davis, S.C., Long, S.P., 2010. Feedstocks for lignocellulosic biofuels. Science 329, 790-792.

Tilman, D., Hill, J., Lehman, C., 2006. Carbon-negative biofuels from low-input highdiversity grassland biomass. Science 314, 1598-1600.

Tilman, D., Socolow, R., Foley, J.A., Hill, J., Larson, E., Lynd, L., Pacala, S., Reilly, J. Searchinger, T., Somerville, C., Williams, R., 2009. Beneficial biofuels. The food, energy, and environment trilemma. Science 325, 270-271.

Twine, T.E., Kustas, W.P., Norman, J.M., Cook, D.R., Houser, P.R., Meyers, T.P., Prueger J.H., Starks, P.J., Wesely, M.L., 2000. Correcting eddy-covariance flux underestimates over a grassland. Agric. For. Meteorol. 103, 279-300.

US_EPA, 2010. In: Assessment of Standard Division of Transportation and Air Quality (Ed.), Renewable Fuel Standard Program (RFS2) Regulatory Impact Analysis. United States Environmental Protection Agency.

Webb, E.K., Pearman, G.I., Leuning, R., 1980. Correction of flux measurements for density effects due to heat and water-vapor transfer. Q. J. Roy. Meteorol. Soc. $106,85-100$.

Wilson, K., Goldstein, A., Falge, E., Aubinet, M., Baldocchi, D., Berbigier, P., Bernhofer, C., Ceulemans, R., Dolman, H., Field, C., Grelle, A., Ibrom, A., Law, B.E., Kowalski, A., Meyers, T., Moncrieff, J., Monson, R., Oechel, W., Tenhunen, J., Valentini, R. Verma, S., 2002. Energy balance closure at FLUXNET sites. Agric. For. Meteorol. $113,223-243$.

Zeri, M., Sá, L.D.A., 2010. The impact of data gaps and quality control filtering on the balances of energy and carbon for a Southwest Amazon forest. Agric. For. Meteorol. 150, 1543-1552. 